\title{
Kangaroo method: perceptions on knowledge, potencialities and barriers among nurses
}

\author{
Método canguru: percepções sobre o conhecimento, potencialidades e barreiras entre enfermeiras \\ Método canguru: percepciones sobre el conocimiento, potencias y barreras entre enfermeros
}

\author{
Débora de Oliveira Ferreira ${ }^{1}$ (1) \\ Maria Paula Custódio Silva ${ }^{1}$ (D) \\ Tanyse Galon ${ }^{2}$ (D) \\ Bethania Ferreira Goulart ${ }^{3}$ (D) \\ Jesislei Bonolo do Amaral ${ }^{2}$ (D) \\ Divanice Contim ${ }^{2}$ (D)
}

1. Universidade Federal do Triângulo

Mineiro, Mestrado em Atenção à Saúde.

Uberaba, MG, Brasil.

2. Universidade Federal do Triângulo Mineiro,

Departamento de Enfermagem na Assistência

Hospitalar. Uberaba, MG, Brasil.

3. Universidade Federal do Triângulo

Mineiro, Departamento Didático Científico

de Enfermagem em Educação e Saúde

Comunitária. Uberaba, MG, Brasil.
Corresponding author:

Divanice Contim.

E-mail:d.contim@uol.com.br

Submitted on $04 / 04 / 2019$.

Accepted on 07/30/2019.

DOI: 10.1590/2177-9465-ean-2019-0100

\section{Abstract}

Objective: To analyze the knowledge, potentialities and barriers related to the implantation of the Kangaroo Method in the perception of nurses who work in the maternal-infant units of a school hospital. Method: An exploratory-descriptive research with a qualitative approach, guided by the Policy of Humanized Attention to the Low Weight Newborn, Kangaroo Method. Held between January and March 2018, with eight nurses from a maternal-infant unit. Data was collected between January and March 2018, through semi-structured interviews, transcribed and submitted to Thematic Content Analysis associated with Atlas T version eight resources. Results: Three categories emerged: Barriers to the development of the Kangaroo Method; Knowledge about the Kangaroo Method; and Potentialities of the Kangaroo Method. Conclusions and implications for practice: The nurses' speeches revealed partial knowledge, lack of practical experience and barriers related to team resistance and lack of institutional support, although they considered the method with potential benefits to provide bonding and indicate continuing education as a necessary strategy for its implementation.

Keywords: Infant; Newborn; Kangaroo-Mother Care Method; Nurses; Knowledge.

\section{RESUMO}

Objetivo: Analisar o conhecimento, as potencialidades e as barreiras relacionadas à implantação do Método Canguru, na percepção de enfermeiras que atuam nas unidades materno-infantil de um hospital-escola. Método: Pesquisa exploratório-descritiva, com abordagem qualitativa, orientada pela Política de Atenção Humanizada ao Recém-Nascido de Baixo Peso, Método Canguru. Realizada entre janeiro e março de 2018, com oito enfermeiras de unidade materno-infantil. Os dados foram coletados no período entre janeiro e março de 2018, por meio de entrevistas semiestruturadas, transcritas e submetidas à Análise de Conteúdo Temática associada aos recursos do Atlas Ti versão oito. Resultados: Emergiram três categorias: Barreiras para o desenvolvimento do Método Canguru; Conhecimento sobre o Método Canguru; e Potências do Método Canguru. Conclusão e implicações para a prática: Os discursos das enfermeiras revelaram conhecimento parcial, ausência de experiência prática e barreiras relacionadas à resistência da equipe e à falta de apoio institucional, embora considerem o método com potenciais benefícios para proporcionar a construção de vínculo e indiquem a educação permanente como estratégia necessária para sua implantação.

Palavras-chave: Recém-nascido prematuro; Método Canguru; Enfermeiros e Enfermeiras; Enfermagem Materno-Infantil.

\section{REsumen}

Objetivo: Analizar el conocimiento, las potencialidades y las barreras relacionadas con la implantación del Método Canguro en la percepción de enfermeras que actúan en unidades materno-infantil de un hospital-escuela. Método: Investigación exploratoria-descriptiva, con abordaje cualitativo, orientada por la Política de Atención Humanizada al Recién Nacido de Bajo Peso, Método Canguro. Realizada entre enero y marzo de 2018, con ocho enfermeras de unidad materno-infantil. Los datos fueron recolectados en el período entre enero y marzo de 2018, a través de entrevistas semiestructuradas, transcritas y sometidas al Análisis de Contenido Temático asociado a los recursos del Atlas Ti versión ocho. Resultados: Emergieron tres categorías: Barreras para el desarrollo del Método Canguro; Conocimiento sobre el Método Canguro; y Potencias del Método Canguro. Conclusión e implicaciones para la práctica: Los discursos de las enfermeras revelaron conocimiento parcial, ausencia de experiencia práctica y barreras relacionadas con la resistencia del equipo y la falta de apoyo institucional, aunque consideren el método con potenciales beneficios para proporcionar la construcción de vínculo e indiquen la educación permanente como estrategia necesaria para su implantación.

Palabras clave: Recién Nacido; Método Canguro; Enfermeros y Enfermeras; Enfermería Materno-Infantil. 


\section{INTRODUCTION}

The Kangaroo Method (KM) is a neonatal care model that allows, in a precocious way, skin-to-skin contact between the mother and the Preterm Newborn (PN) with low weight, providing a bigger parental involvement in caring for their child, even after hospital discharge. ${ }^{1,2}$ This method was developed in 1979 by Reys Sanabria and Héctor Martínez, in the city of Bogotá, Colombia, as a result of the lack of infrastructure in the caring of this age group. ${ }^{3}$

In Brazil, the KM was integrated as part of policy guidelines related to health care of PNs with low weight, included in the Prenatal and Birth Humanization Program, instituted by the Ministry of Health, under Ordinance/GM No. 693, of July $5^{\text {th }}$, 2000 which adopted the method as an essential strategy in the promotion of changes focused on the humanization of assistance and on the principle of family citizenship, updated by Ordinance GM/MS No. 1,683 , of July $12^{\text {th }}, 2007$. In the organizational context, Ordinance GM/MS No. 930, of May $10^{\text {th }}, 2012$, defined the guidelines and goals for the organization of a humanized full attention to the newborn in a severe or potentially severe condition and the classification and qualification criteria of neonatal unit beds in the scope of the SUS. ${ }^{2,4}$ The adoption of this method becomes essential in the promotion of institutional changes turned to humanization of assistance. ${ }^{5}$

The KM has as principle to promote greater affective bond and thermal stability, to contribute to nosocomial infection risk reduction, to reduce stress and pain in the Newborn (NB), to increase breastfeeding rates and to improve neurobehavioral and psycho-affective development, providing a better family-health team relationship, decreasing the number of readmissions and contributing to optimization of Neonatal Intensive Care Units (NICU) and Neonatal Intermediate Care beds. ${ }^{2,5}$

This method is performed in three phases, allowing professionals, through technical standards, to produce a humanized assistance, in the hospital and ambulatory scopes, to pregnant and postpartum women and to the low weight PN. The first phase begins at the prenatal stage of the high-risk pregnancy, followed by the newborn's hospitalization in the NICU and/or in the Neonatal Intermediate Care Unit. In these spaces, family reception and the first approach of parents and relatives with their babies take place. The second phase begins with conducting the NB to the Kangaroo Intermediate Care Unit (KICU). In this phase, parents are invited to be near their babies full time, sparing daily care under supervision and orientation of the health staff, particularly the nursing team. In the third phase, the baby is discharged home if it meets the criteria of having a minimum weight of $1,600 \mathrm{~g}$, if it is able to suck the maternal breast in an effective way and if the mother is feeling confident and motivated to do home care, and has the necessary conditions to turn to the hospital unit in case of emergency. ${ }^{2}$

In this perspective, the KM surpasses the neonatal unit space and is performed in the family environment itself, beginning the phase of Home Kangaroo. 1,2,7,8 This is characterized by ambulatory or home follow-up, until the baby reaches $2,500 \mathrm{~g}$, enlightening the family that the first consultation is to be made after the first 48 hours from hospital discharge. Follow-up is performed according to growth and development standards preconized by the Ministry of Health. ${ }^{2,8}$

The KICU is an environment with a qualified service and babies' accompaniment team and corroborates the effectiveness and quality of care, with this, what is expected of this assistance model occurs: decrease of healthcare related infections, decrease of prematurity apnea, breastfeeding stimulation, more efficient thermal control, proper sensory stimulation, favoring of mother and child bond, improvement in neurobehavioral development and in the relationship between the family and the health team, greater competency and confidence of the parents in handling the low weight NB, even after hospital discharge. ${ }^{9}$

The resistance related to the implantation of the KM may occur due to the lack of experience of the professionals in this assistance model. Thus, practical experiences related to the KM have to be listed, sensitizing the professionals involved, in order to avoid the mechanization of work. ${ }^{10}$

The nurse's practice in this care model has interventions related to the organizational culture of the work environment such as interactions with evidences that justify the importance of the Kangaroo Method. ${ }^{10}$ In order to make the process of the assistance model implantation effective, sensitizing and permanent education of professionals are necessary, based on ethical-political and socio-educational dimensions, along with scientific technical learning. ${ }^{11}$

Amongst the proposed actions that stimulate the implantation of the KM and its advantages to the low weight PN and their relatives, given their social context, the aim is to analyze the knowledge, potentialities and barriers related to the implantation of the Kangaroo Method in the perception of nurses who work in the maternal-infant units of a teaching hospital.

\section{METHOD}

Study of a qualitative approach, conducted in the MaternalInfant Unit of a University Hospital of a country town in the state of Minas Gerais. The theoretical and conceptual framework of this study is based on the Humanized Care for Low Weight Newborn Policy - Kangaroo Method, used as a guide in the implementation and orientation related to the method in Brazil. ${ }^{2}$

The study included nurses who met the inclusion criteria: acting in the sectors included in the Maternal-Infant Unit (Joint Accommodation, Neonatal Intermediate Care Unit and Neonatal Intensive Care Unit), having more than a year of active duty and not being away from work during the period of data production.

All the nurses in the sectors involved were invited to participate in the survey, and they were approached in their work shifts, from the presentation of the study's objective. The 
number of participants in the study was constituted through the theoretical guidelines, reaching theoretical saturation from the moment when no new elements were found in the speeches. ${ }^{13}$

For performing the interviews, an instrument of data gathering was built, fitted by means of a pre-test with two residents of the neonatal nursing area. After this procedure, the interviews were done in two stages: the first with participants' characterization and the second, composed by open questions: Do you know the kangaroo method in all its stages? Do you believe that the kangaroo method is a humanized measure? Do you feel the need to implant this method in the Unit you work in? Talk to me about the importance of this method to nursing assistance. Talk about the meanings you attribute to the Kangaroo Method as a nurse. Would you like to say something else about the subject?

The average duration of each interview was 18 minutes and they took place in a private room in the participants' allotment sector. To ensure privacy, the interviewees were identified by the letter $E$, followed by a sequential number to the performed interview (E1 ...E8). Data gathering was made between January and March 2018. After the interviews, the recordings were fully transcribed, ensuring the reliability of the discursive contents.

Data was stored in the software Atlas ti version 8 , for organization and management. The analytical process was based on the Thematic Content Analysis, oriented by the chosen theoretical-conceptual framework. To such end, three phases were developed: pre-analysis, material exploitation or codification and treatment of the obtained results/interpretation. ${ }^{14}$

The study was submitted to the Research Ethics Committee of Universidade Federal do Triângulo Mineiro (UFTM) and approved under the Consolidated Opinion No. 2.175.88, CAAE 68730417.7 .0000 .5154 . The requirements established by Resolution No. 466/12 by the National Health Council (NHC) were respected, which provides rules and guidelines that regulate studies involving human beings.

\section{RESULTS}

The study included speeches of eight nurses who work at the Maternal-Infant Unit, two being from the Joint Accommodation sector, two from the Neonatal Intermediate Care Unit and four from the Neonatal Intensive Care Unit, in the age group between 24 and 35 years old. The time of training and professional experience varied between two and 11 years, and the work time at the institution's Maternal-Infant Unit was from two to five years. All the participating professionals have a weekly workload of 36 hours and have no other employment. Among the participants, three nurses did not have any post-graduate degree, four had a lato sensu specialization in the field of Nursing in Neonatology and Pediatrics and, of them, one has a stricto sensu post-graduation, in the modality of a master's degree.

After analysis of the transcripts of the interviews, the categorization of the speeches was performed, from where there emerged three categories, illustrated in Figure 1.
Figure 1. Categories and subcategories emerged from the interviews.

\begin{tabular}{|l|l|l|}
$\begin{array}{l}\text { Knowledge about } \\
\text { the Kangaroo } \\
\text { Method }\end{array}$ & $\begin{array}{l}\text { Potentialities of } \\
\text { the Kangaroo } \\
\text { Method }\end{array}$ \\
$\begin{array}{l}\text { - Partial } \\
\text { knowledge } \\
\text { practice of } \\
\text { experience. }\end{array}$ & $\begin{array}{l}\text { - Bonding: "the baby } \\
\text { and the parents } \\
\text { evolve together". } \\
\text { - Experiences from } \\
\text { other institutions. } \\
\text { - Mother/Family } \\
\text { insertion in the care } \\
\text { process. } \\
\text { Kangaroon Method }\end{array}$ \\
- Family and staff \\
approach promotion. \\
- Stress and pain \\
reduction. \\
- Humanized \\
assistance. \\
- Support network.
\end{tabular}

\section{Category 1: Knowledge about the Kangaroo Method Partial knowledge: lack of practical experience}

For the participants, it is essential that the implementation of the KM be effective and of quality and they refer to have theoretical knowledge about this assistance model, even not being widespread in their professional practice. Given this, lack of experience and familiarity with the actions proposed in the $\mathrm{KM}$ was observed among the professionals. In this subcategory, in which the knowledge about the method was revealed, some participants reported partial knowledge about the theme, in view that, even though they had theoretical knowledge, they have never worked with this strategy in their professional practice.

\section{[...] No, I don't know the whole Kangaroo Method [...] (E1)}

[...] Yes, I know the Kangaroo Method, but I have no knowledge of all the steps in practice [...] (E3)

[...] I do know the method in theory, but I haven't had the opportunity to work with it in practice [...] (E6)

\section{Experiences from other institutions}

Among the professionals that reported to know the KM, qualification and approach with successful experiences from other health services was a crucial aspect to knowledge and skills development about the theme.

[...] I have already studied about the Kangaroo Method and had the opportunity to go to a hospital where all the stages of the method were performed [...] (E2)

\section{Category 2: Potencialities of the Kangaroo Method Bond building: "the baby and the parents evolve together"}

Regarding the potentialities of the KM, the study's participants pointed out bond creation and the construction of affective 
ties between baby and mother, spreading to bond promotion with the father, the relatives or other people close to the baby and that can be a part of this strategy. Bonding happens in a successive way and, the more opportunities of parents and baby interaction realized, the greater the probability of affective response, decreasing the risk of negligence, abandonment or fear of approaching the baby.

[...] Forme, the Kangaroo Method means a strengthened bond with parents. It is a measure that has only benefits for both mother and baby, it leads to an increase in family stimulus in wanting to spend more time with the hospitalized baby [...] (E3)

[...] I see that the Kangaroo could improve specially the bond of some mothers and fathers with the babies, you know?! There are families that come here and get kind of frightened, even scared of touching the baby and, when we're going to encourage them to pick the baby up, teach them how to bath it and even when we start to put it next to the breast for breastfeeding, we feel and see how much it changes. The baby and the parents evolve together! This is what I believe has more meaning for me [...] (E6)

\section{Mother/Family insertion in the caring process}

Besides bonding, the interviewed professionals also referred that the KM can be a stimulus or a possibility for the insertion of mother, father and relatives in the baby care process, which can create more trust and preparation among them as regards care, after hospital discharge.

[...] It involves more than the low weight and premature baby care staff, it enables a bigger adherence of relatives and this helps in their insertion in the baby's care and development [...] (E5)

\section{Family and staff approach promotion}

According to the interviewed nurses, one of the benefits of the KM is the link produced also between family and staff, a process that creates collaborative relationships, includes both the baby's and the family's demands, strengthens the actions of the nursing staff and generates a more effective, joint and significant baby care assistance.

$[\ldots]$ it is also important to the nurse, because it helps in breastfeeding and in the contact with the family, bringing them closer to the health staff as well [...] (E4)

\section{Stress and pain reduction}

The participants consider that the KM provides allowances for stress and pain reduction, caused by invasive interventions in the neonate.
[...] I believe the kangaroo method is a humanized measure because it helps with the premature baby's pain, it helps to calm the baby [...] (E4)

\section{Humanized assistance}

In the speeches, regarding humanized assistance related to the KM, the participants revealed possibilities of effective participation of parents in the process of taking care of the NB. The importance of humanized care practices establishes improvements in family-related care to the NB and, with this, increasingly promotes a better quality assistance and a greater promotion of the professionals involved and of the triad of parents/relatives/NB.

[...] I agree that it is indeed a humanization measure, because it gives the mother who has her son hospitalized in a ICU, for example, the opportunity to hold him, to be in contact with her son for a longer time [...] (E7)

\section{Support network}

The support network is seen by the participants as a possibility of improvement in the accompaniment of the parents and the NB, after hospital discharge.

[...] The baby will be better assisted, at discharge, in the ambulatory modality, that sometimes gets flawed because of this planning, which the method makes possible. It offers greater support to parents and an enlarged support network [...] (E2)

\section{Category 3: Barriers to the development of the Kangaroo Method Staff resistance}

The resistance of the assistance team for the NB is due to the lack of the professionals' capacity and sensitivity involving such practice; insecurity and lack of knowledge damage the adherence of the professional. The fact that this model is not widespread bestows resistance to the proposition.

[...] We see a lot of resistance from some professionals in the staff, when there is the desire to put a baby in the parents' laps, but I think the staff as a whole must be empowered and informed about the benefits proposed by the method because our main focus here are the babies and their improvement [...] (E5)

[...] I think it would be important to implement the Kangaroo in the hospital, but I think it would take time until people adhere to the idea because there is a lot of resistance when something new is implanted here in our hospital [...] (E7) 


\section{Institutional support in the promotion of the KM}

The lack of structure reported by the professionals is mainly connected to the fact that the institution has no qualified material or human resources to operate in the assistance of a $\mathrm{KICU}$; therefore, these factors have an impact on the implantation of this care model.

[...] In my working unit the method hasn't been implanted yet, and that would be really beneficial to parents and to the premature NB. But it lacks in matter of structure, and also some things could already have been done, but it depends on others instances [...] (E2)

[...] I think it is necessary to implant the method in the unit I work, because it is not implemented. Rarely do you see the baby in skin-to-skin contact with the mother. It's pretty hard to find that in the ICU [...] (E4)

\section{DISCUSSION}

The participating nurses reported not knowing all the stages of the KM or knowing it partially, in their daily routines. This fact may derive from curriculum deficiencies and from the lack of preparation of professionals for this care practice. A study conducted in Brazilian maternity hospitals officially qualified by the Ministry of Health, pointed out the necessity of periodic training through continuing education to provide information and to improve service infrastructure, effectively reflecting in the humanization of care. ${ }^{15}$ The trainings are clear eligibility criteria for better practices in the acceptable use of direct care incorporated by the health system, contributing to neonatal survival. ${ }^{16,17}$

It is known that continuing training is the way to qualify and prepare nurses for the development of skills related to the $\mathrm{KM}$; however, the relation or association between knowledge and academic degree is not observed, which suggests that these nurses may be less focused on the opportunity for change and, in consequence, on working with this practice. ${ }^{17-19}$ Therefore, the multipliers must ensure benefits that involve attitude changes and, at the same time, a practice grounded on the policy to have a better awareness on the part of professionals.

The success of the method's implementation is not only linked to trainings: it is necessary that the professionals are sensitized and motivated. Difficulties are found even after the educational activities and, thus, it is suggested to insert innovative educational strategies in this context, establishing partnerships with other institutions officially qualified for technical visits. ${ }^{19}$ Thus, training is based on the evidences produced by the research and conducted according to the current best practices in education. ${ }^{18,19}$

It is pertinent that the institution's managers sensitize about the implementation of good practices in neonatal health, aiming at the quality of the assistance provided, the training of the professionals involved and the offering of appropriate conditions for the execution of the work developed and a humanized care towards the NB and its relatives.

Regarding the potentialities of the KM, the study's participants highlighted bond creation and the construction of affective ties between mother and child, extensive to the father and the relatives. Even though the $\mathrm{KM}$ is not a model implanted in the nurses' care practice, the reports point out that they recognize it as an important way of interaction between the baby and the family, which increases the bond and fosters its better evolution. Parents' and relatives' insertion in the process of taking care of the low weight PN, in a premature way, promotes affective bond and this results in benefits for the triad, minimizing the negative effects related to coping with hospitalization, treatment and recovery of the child. ${ }^{20,21}$

Skin-to-skin contact is part of the method and begins in a premature way through touching, evolving up to the kangaroo position. Providing a bond and welfare is recommended during painful procedures because it promotes pain and stress relief to the low weight PN. ${ }^{2,13}$ A Brazilian study evidenced that skin-toskin contact influences positively in weight gain and in the time of hospitalization of newborns. ${ }^{22}$

These measures impact directly on the humanization process of care and act as technological interventions focused on the recovery and safety of the low weight PN. Thus, in order to make this process effective, the institution must be concerned with the relational and structural environment of the maternalinfant units. ${ }^{23,24}$

Premature interventions, performed by the Nursing staff and other acting professionals in a neonatal care unit and leveraged by the $\mathrm{KM}$, are fundamental to an adaptive care that allows parents to explore their fears, longings, doubts and insecurities facing the process of taking care of the low weight PN. ${ }^{19}$

The creation of a relationship between the staff and relatives favors the fortification of a supporting network, during the child's hospitalization, allowing a better adaptation to the new environment. ${ }^{24}$ This process indicates the extensive warranty of the care started in the neonatal units and at home discharge, mediated by educational actions developed by the health staff, in and out the hospital environment. In this context, the health staff must support and encourage the father's presence during the whole process..$^{25,26}$

Although the professionals know the importance of the method, they find barriers to its implementation and execution. There is resistance from the multidisciplinary staff to fully accept the proposition as an interdisciplinary project that has a real impact on global neonatal care quality. ${ }^{27}$ It is believed that this is caused by lack of skills, work overload and lack of human, material and structural resources. ${ }^{27}$

So that this strategy can develop, some conditions that prioritize the care with the triad of NB, mother and family are needed, in order to achieve satisfactory results and/or effectiveness in the proposed actions. The reflections about the 
insertion of the KM in the clinical guidelines scenario and in the field of health technologies, as well as the matches found in the literature regarding Family Centered Care may be useful in the dissemination strategies and in the effective incorporation of these propositions into neonatal practices. ${ }^{28}$

\section{CONCLUSIONS AND IMPLICATIONS FOR PRACTICE}

Through the nurses' speeches, this study revealed the lack of or fragility in the knowledge about the impact of the $\mathrm{KM}$ on the lives of NBs and their relatives. The lack of experience with this care model was quoted by the participants; however, they recognize the existence of barriers related to the nursing staff, as well as the absence of a structure needed to the implantation of the method.

The reduced number of participants and the representation in a single scenario is considered a limitation of the study, highlighting the need to perform new researches on this subject. The theoretical knowledge about the KM benefits was reported by the participants and identified as potentialities to the implantation of the method; it is concluded that, in order to achieve a more effective and quality assistance, there is a need for the commitment of the institution and of the professionals involved in care. Without previous knowledge, these workers did not presented affinity with this care model, coming from lack of training and organizational structure for the use of the $\mathrm{KM}$ as a daily practice in service.

\section{REFERENCES}

1. Araújo AMG, Melo LS, Alves de Souza MEDC, Freitas MMSM, Lima MGL, Lessa RO. A experiência do método canguru vivenciada pelas mães em uma maternidade pública de Maceió/AL. Rev Iberoam Educ Invest Enferm [Internet]. 2016 jul; [cited 2018 jan 23]; 6(3):1929. Available from: http://www.enfermeria21.com/revistas/aladefe/ articulo/210/a-experiencia-do-metodo-canguru-vivenciada-pelasmaes-em-uma-maternidade-publica-de-maceioal-brasil/

2. Ministério da Saúde (BR). Secretaria de Atenção à Saúde. Atenção humanizada ao recém-nascido. Método Canguru: Manual Técnico [Internet]. Brasília (DF): Ministério da Saúde; 2017; [cited 2018 jan 23]. Available from: http://bvsms.saude.gov.br/bvs/publicacoes/ atencao_humanizada_metodo_canguru_manual_3ed.pdf

3. World Health Organization (WHO). Born too soon: the global action report on preterm birth. Geneva: WHO; 2012. Available from: https:// www.who.int/pmnch/media/news/2012/201204_borntoosoon-report. pdf

4. Ministério da Saúde (BR). Portaria n. 930, de 10 de maio de 2012. Define as diretrizes e objetivos para a organização da atenção integral e humanizada ao recém-nascido grave ou potencialmente grave e os critérios de classificação e habilitação de leitos de Unidade Neonatal no âmbito do Sistema Único de Saúde (SUS). Diário Oficial da União, Brasília (DF), 10 mai 2012. Available from: http://bvsms.saude.gov.br/ bvs/saudelegis/gm/2012/prt0930_10_05_2012.html

5. Franco MP, Alves CP.O impacto do método mãe canguru no processo de aprendizagem de prematuros de baixo peso: Revisão da literatura. Cad Ter Ocup UFSCar [Internet]. 2014; [cited 2018 jan 23]; 22(1):16374. Available from: https://doi.org/10.4322/cto.2014.018
6. Aires LCP, Santos EKA, Bruggemann OM, Backes MTS, Costa R. Referência e contrarreferência do bebê egresso da unidade neonatal no sistema de saúde: percepção de profissionais de saúde da Atenção Primária. Esc Anna Nery [Internet] 2017; [cited 2018 jan 23] 21(2):e20170028. Available from: http://dx.doi.org/10.5935/14148145.20170028

7. Jack BA, Mitchell TK, O'Brien MR, Silverio SA, Knighting K. A qualitative study of health care professionals' views and experiences of paediatric advance care planning. BMC Palliat Care [Internet]. 2018 jul; [cited 2018 jan 23]; 17(93). Available from: https://doi.org/10.1186/s12904018-0347-8

8. Ely VHMB, Cavalcanti PB, Silveira JTT, Klein MF, Soares Junior A Atributos ambientais desejáveis a uma unidade de alojamento conjunto Método Canguru a partir de uma experiência de projeto participativo. Ambient Constr [Internet]. 2017; [cited 2018 jan 23]; 17(2):119-34. Available from: http://dx.doi.org/10.1590/s1678-86212017000200149

9. Entringer AP, Gomes MASM, Pinto M, Caetano R, Magluta C, Lamy ZC. Análise de custos da atenção hospitalar a recém-nascidos de risco: uma comparação entre Unidade Intermediária Convencional e Unidade Canguru. Cad Saúde Pública [Internet]. 2013 jun; [cited 2019 mai 31];29(6):1205-1216. Available from: http://www.scielo.br/pdf/csp/ v29n6/a17v29n6.pdf

10. Silva LJ, Leite JL, Silva TPS, Silva IR, Mourão PP, Gomes TM. Desafios gerenciais para as melhores práticas do Método Canguru na UTI Neonatal. Rev Bras Enferm [Internet]. 2018; cited 2019 mai 31] 71(Suppl 6):2783-2791. Available from: http://dx.doi.org/10.1590/00347167-2018-0428

11. Parisi TCH, Coelho ERB, Melleiro MM. Implantação do Método MãeCanguru na percepção de enfermeiras de um hospital universitário. Acta Paul Enferm [Internet]. 2008; [cited 2019 jun 01]; 21(4):575580. Available from: http://www.scielo.br/scielo.php?script=sci arttext\&pid=S0103-21002008000400007\&lng=en DOI: http://dx.doi. org/10.1590/S0103-21002008000400007

12. Menezes MAS, Garcia DC, Melo EV, Cipolotti R. Recém-nascidos prematuros assistidos pelo Método Canguru: avaliação de uma coorte do nascimento aos seis meses. Rev Paul Pediatr [Internet]. 2014 jun; [cited 2018 jan 23]; 32(2):171-77. Available from: http://dx.doi. org/10.1590/0103-0582201432213113

13. Hennink MM, Kaiser BN, Marconi VC. Code Saturation Versus Meaning Saturation: How Many Interviews Are Enough? Qual Health Res [Internet]. 2017 Mar; [cited 2019 fev 20]; 27(4):591-608. Available from: https://doi.org/10.1177/1049732316665344

14. Minayo MCS. O Desafio do Conhecimento: Pesquisa Qualitativa em Saúde. 10ª ed. São Paulo: HUCITEC; 2014.

15. Gontijo TL, Xavier CC, Freitas MIF. Avaliação da implantação do Método Canguru por gestores, profissionais e mães de recém-nascidos. Cad Saúde Pública [Internet]. 2012 may; [cited 2018 jan 23]; 28(5):935-44. Available from: http://dx.doi.org/10.1590/S0102-311X2012000500012

16. Boundy EO, Dastjerdi R, Spiegelman D, et al. Kangaroo Mother Care and Neonatal Outcomes: A Meta-analysis. Pediatrics [Internet]. 2016 jan; [cited 2018 jan 23]; 137(1):e20152238. Available from: http://dx.doi. org/10.1542/peds.2015-2238

17. Chan GJ, Labar AS, Wall S, Atun R. Kangaroo mother care: a systematic review of barriers and enablers. Bull World Health Organ [Internet] 2016; [cited 2018 jan 23]; 94:130-141. Available from: http://dx.doi. org/10.2471/BLT.15.157818

18. Seidman G, Unnikrishnan S, Kenny E, Myslinski S, Cairns-Smith S, Mulligan B, et al. Barriers and Enablers of Kangaroo Mother Care Practice: A Systematic Review. PLoS One [Internet]. 2015 may; [cited 2018 jan 23]; 10(5):e0125643. Available from: https://dx.doi.org/ doi:10.1371/journal.pone.0125643

19. Bergh AM, Charpak N, Enzeonodo A, Udani R, Van Rooyen E. Education and Training Working Group: Education and training in the implementation of kangaroo mother care. S Afr J Child Health [Internet]. 2012; [cited 2018 jan 23]; 6(2):38-45. Available from: https://dx.doi. org/10.7196/SAJCH.417 
20. Silva ARE, Garcia RN, Guarigua DA. Método Canguru e os Benefícios para o recém-nascido. Revista Horus [Internet]. 2013; [cited 2018 jan 23]; 8(2):1-10. Available from: http://revistaadmmade.estacio.br/index. php/revistahorus/article/viewFile/4029/1856

21. Gesteira ECR, Braga PP, Nagata M, Santos LFCS, Barbára $C H$, Ribeiro G. Método canguru: benefícios e desafios experienciados por profissionais de saúde. Rev Enferm UFSM [Internet]. 2016 out/ dez; [cited 2018 jan 23]; 6(4):518-28. Available from: http://dx.doi. org/10.5902/2179769220524

22. Souza AKCM, Tavares ACM, Carvalho DGL, Araújo VC. Weight gain in newborns submitted to skin-to-skin contact. Rev CEFAC [Internet]. 2018 feb; [cited 2018 jan 23]; 20(1):53-60. Available from: http://dx.doi. org/10.1590/1982-021620182018317

23. Ferreira JHP, Amaral JJF, Lopes MMCO. Equipe de enfermagem e promoção do cuidado humanizado em unidade neonatal. Rev Rene [Internet]. 2016 nov/dec; [cited 2019 jan 23]; 17(6):741-9. Available from: https://doi.org/10.15253/2175-6783.2016000600003

24. Silva RA, Barros MC, Nascimento MHM. Conhecimento de técnicos de enfermagem sobre o método canguru na unidade neonatal. Rev Bras Promoç Saúde [Internet]. 2014 jan/mar; [cited 2018 jan 23]; 27(1):124-30. Available from: https://doi.org/10.5020/18061230.2014.p124
25. Testoni TT, Aires LCP. O Método Canguru como um veículo para o empoderamento materno. REFACS (online) [Internet]. 2018; [cited 2018 jan 23]; 6(Supl 2):611-19. Available from: https://doi.org/10.18554/ refacs.v6i0.2957

26. Custódio ZAO, Crepaldi MA, Linhares MBM. Redes sociais de apoio no contexto da prematuridade: perspectiva do modelo bioecológico do desenvolvimento humano. Estud Psicol (Campinas) [Internet] 2014 jun; [cited 2018 jan 23]; 31(2):247-55. Available from: https://doi. org/10.1590/0103-166X2014000200010

27. Mendes GVS, Rocha SS, Sales JCS, Araújo OD, Araújo LO. Kangoroo Care Method at Neonatal Intensive Care Unit. Rev Enferm UFP [Internet]. 2015 oct/dec; [cited 2018 jan 23]; 4(4):68-74. Available from: https://doi.org/10.26694/reufpi.v4i4.4958

28. Hennig MAS, Gomes MASM, Morsch DS. Atenção humanizada ao recém-nascido de baixo-peso. Método Canguru e cuidado centrado na família: correspondências e especificidades. Physis [Internet] 2010; [cited 2019 jul 15]; 20(3):835-52. Available from: http://dx.doi. org/10.1590/S0103-73312010000300008 